\title{
THE CHEMICAL AND BIOLOGICAL CONTROL OF LYMNAEA TRUNCATULA IN NATURAL WATERCRESS BEDS IN THE LIMOUSIN REGION (FRANCE)
}

\author{
RONDELAUD D.*, VAREILLE-MOREL C.**
}

\section{Summary :}

The snails present in 17 natural watercress beds have been treated during 1 or 2 years by a control associating the use of a molluscicide $\left(\mathrm{CuCl}_{2}\right)$ and the introduction of a predatory snail, Zonitoides nitidus. Lymnea truncatula was eliminated in only one year of treatment in 14 stations, and in two years in the three others. Elimination of other aquatic pulmonate snails was effected in two years for L. glabra, in 3 years for L. palustris, and in only one year for Physa acuta. Z. nitidus has disappeared from 12 watercress beds during the 4 th year after treatment; in the five others, the numbers of this predator increased during 1 or 2 years and then decreased before their disappearance.

KEY WORDS : Biological control. Chemical control. Fasciolosis. Lymnaea truncatula. Watercress bed.

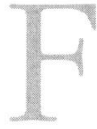

asciolosis hepatica can be prevented by eradicating the snail which acts as intermediate host in the parasite's life cycle (Taylor, 1964). Numerous organic or chemical molluscicidal agents have been proposed to date (reviewed by Euzeby, 1971), however, the principal difficulty encountered with their use concerns the amphibious nature of Lymnaea truncatula which allows it to escape toxic substances by leaving the water and subsequently recolonize the treated habitats (Rondelaud, 1978a).

Eradication of the snail can be accomplished, however, by associating a) a sublethal dose of a chemical molluscicidal agent $\left(\mathrm{CuCl}_{2}\right)$ in the water drainage system during the spring mating period with $\mathrm{b}$ ) the introduction of a land pulmonate, Zonitoides nitidus, which is an active predator of L. truncatula in JuneJuly. The first trials carried out in the swampy meadows of the Limousin region (France) resulted in eradication of the snail from the majority of its habitats after a single year of treatment (Rondelaud, 1986, 1988).

Since natural watercress beds play an important role in the epidemiology of human fasciolosis in the three departments of the Limousin region (Rondelaud, 1980; Rondelaud and Mage, 1990), we desired to know whether the above-mentioned technique could

\footnotetext{
* Laboratoire d'Histopathologie parasitaire, Faculté de Médecine, 2, rue du Docteur-Raymond-Marcland, F 87025 Limoges Cédex.

** Laboratoire de Malacologie Appliquée, Faculté des Sciences, 123, avenue Albert-Thomas, F 87060 Limoges Cédex.

Send correspondence to : Dr. D. Rondelaud, Faculté de Médecine, 87025 Limoges Cédex.
}

Résumé : Le CONTROLE CHIMIQUe ET BIOLOGIQUe DE LYMNAEA TRUNCATULA MÜLLER DANS LeS CRESSONNIERES NATURELLES DU LIMOUSIN (FrANCE)

Les limnées présentes dans 17 cressonnières naturelles ont été soumises pendant 1 ou 2 années à un contrôle associant l'emploi d'un molluscicide $\left(\mathrm{CuCl}_{2}\right)$ et l'introduction d'un mollusque prédateur, Zonitoides nitidus. La Limnée tronquée a été éliminée en une seule année de traitement dans 14 stations, en deux ans dans les trois autres. L'élimination des autres Pulmonés aquatiques s'est faite en deux ans pour L. glabra, 3 ans pour L. palustris et en une seule année pour Physa acuta. Le prédateur a disparu de 12 cressonnières au cours de la 4 e année après le traitement; dans les 5 autres, les effectifs de $Z$. nitidus se sont accrus pendant 1 ou 2 ans avant de diminuer par la suite et de disparaitre.

MOTS CLES : Contrôle biologique. Contrôle chimique. Cressonnière. Fasciolose. Lymnaea truncatula

control the snail in this particular type of habitat. The present study answers this question by reporting the results from experiments carried out in natural watercress bed sites located in the Department of HauteVienne (France).

The subsoil under the watercress beds was comprised of granite, diorite, or migmatite. The beds were found around springs or from streams which originated from them. Their surface area was less than $20 \mathrm{~m}^{2}$, and the water $\mathrm{pH}$ was between 6.1 and 6.9 with a free calcium ion concentration ranging from 5 to 15 $\mathrm{mg} / \mathrm{l}$.

Our observations were made from 21 watercress beds, of which eleven were solely colonized by $L$. truncatula. Four of these were used as controls (group 1), and seven were subjected to the experimentation (group 2). The ten other beds were comprised of populations of L. truncatula and another aquatic pulmonate: L. glabra (3 cases, group 3), L. palustris (2 cases, group 4), or Physa acuta (5 cases, group 5). The watercress beds from groups 2 to 5 were treated using chemical and biological method (Rondelaud, 1986). Eight liters of $\mathrm{CuCl}_{2}, 2$ $\mathrm{H}_{2} \mathrm{O}$ (at $\left.0.1 \mathrm{mg} / \mathrm{l}\right)$ were poured $(2 \times 4 \mathrm{l})$ into each area in April during the spring mating period of $L$. truncatula. Zonitoides nitidus was then introduced (20 per $\mathrm{m}^{2}$ ) in June or July and a layer of freshly-cut grass was placed. The watercress beds from group 2 were treated for one year, while those of the three other groups were treated for two or three years until the aquatic pulmonates had disappeared. 
Three series of observations were carried out in each site: a) the snails which had survived the winter were counted in April (sampling A), b) the spring generation was counted at the end of June before the streams dried (sampling B), and c) a search for survivors was made in September during the first postsummer rains (sampling C). The investigations were undertaken over a six-year period and involved all snails present in each watercress bed, comprising a search for the following species: L. truncatula, the other aquatic pulmonates, Pisidium casertanum, Succinea putris, and Z. nitidus. All counts were performed by visual search and the snails were left in place after being counted.

The data obtained for each group of watercress beds were then averaged, and standard deviations established, taking into account the date the count was made and the snail species.

The numbers of L. truncatula were rather constant over the six years in the controls from group 1. A mean of 37 to 42 overwintering snails was counted in sampling $\mathrm{A}$; in sampling $\mathrm{B}$ and $\mathrm{C}$, the mean numbers of snails were respectively 87-124 and 41-57 per watercress bed (Fig. 1). The measures taken to control the snails resulted in snail disappearance at sampling $\mathrm{C}$ during the first year (Figs. 2b and d) or by the persistence of a few survivors during the same sampling from group 2 (2 snails at one site, Fig. 2a) and group 4 (Fig. 2c). These snails disappeared naturally (Fig. 2a) or were eradicated at the end of the second year (Fig. 2c). No recolonization of the treated sites was observed during the six years of observation.

There was considerably more variability in the results from the watercress beds of groups 3 to 5 with the three other pulmonates. It was necessary to apply control measures for two years to eliminate L. glabra from its habitats and recolonization of one site was observed during the sixth year (Fig. 2b). It took three years to eliminate $L$. palustris from the sites of which one was also recolonized during the sixth year (Fig. 2c). Pbysa acuta was eliminated in only one year and no recolonization was observed (Fig. 2d).

Pisidium casertanum totally disappeared from the 14 treated watercress beds or persisted in reduced numbers in three sites from group 2 ( 3 to 24 per $\mathrm{m}^{2}$ of habitat). The number of $S$. putris dropped to $50 \%$ of the initial value during application of control measures at group 2 and 3 sites, however, it rapidly repopulated in only one year after cessation of treatment (results not shown).

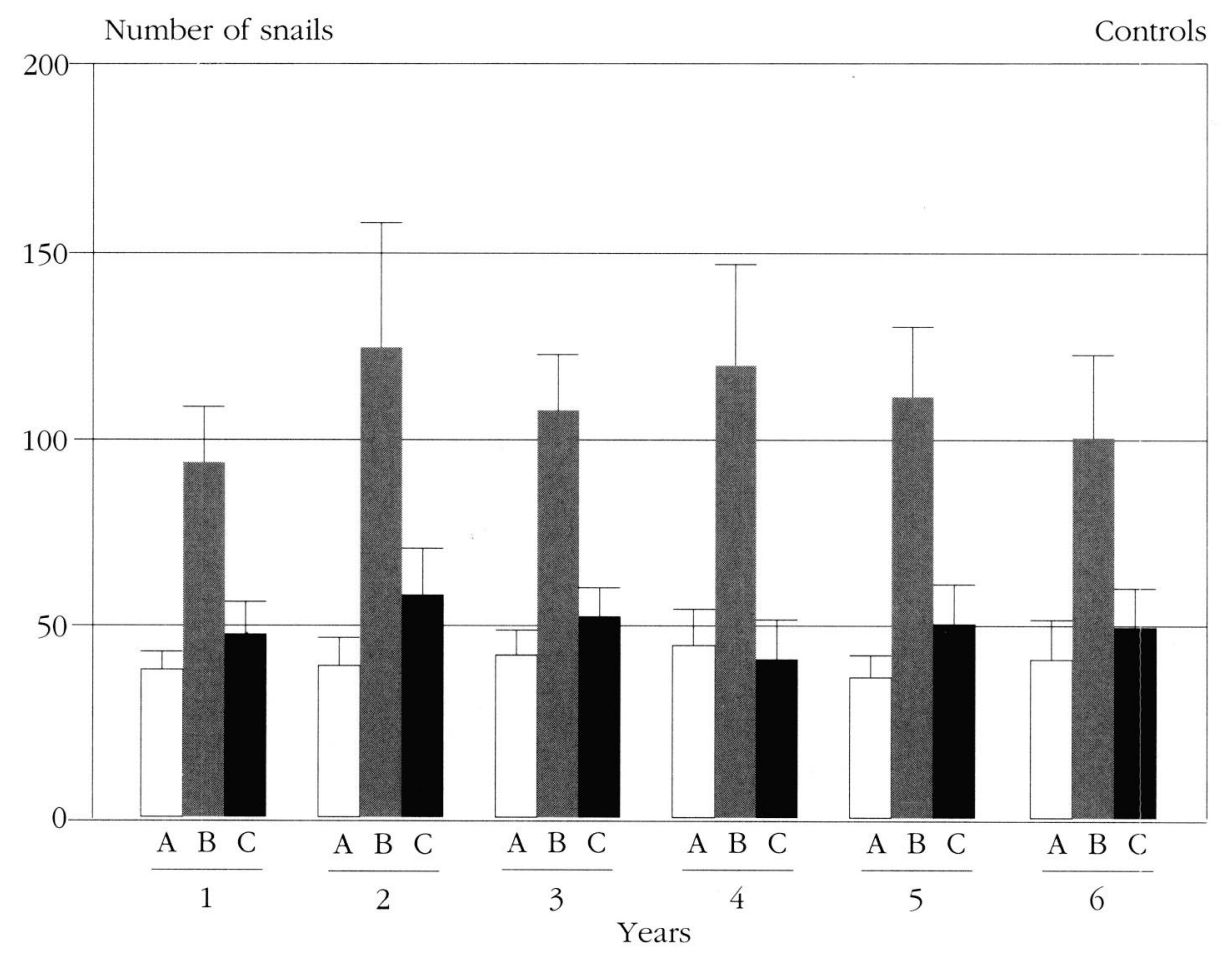

Fig. 1. - Numerical distribution of L. truncatula in control watercress beds during six years. Mean values and standard deviations refer to sampling A, B, and C made respectively in April, at the end of June, and in September. 

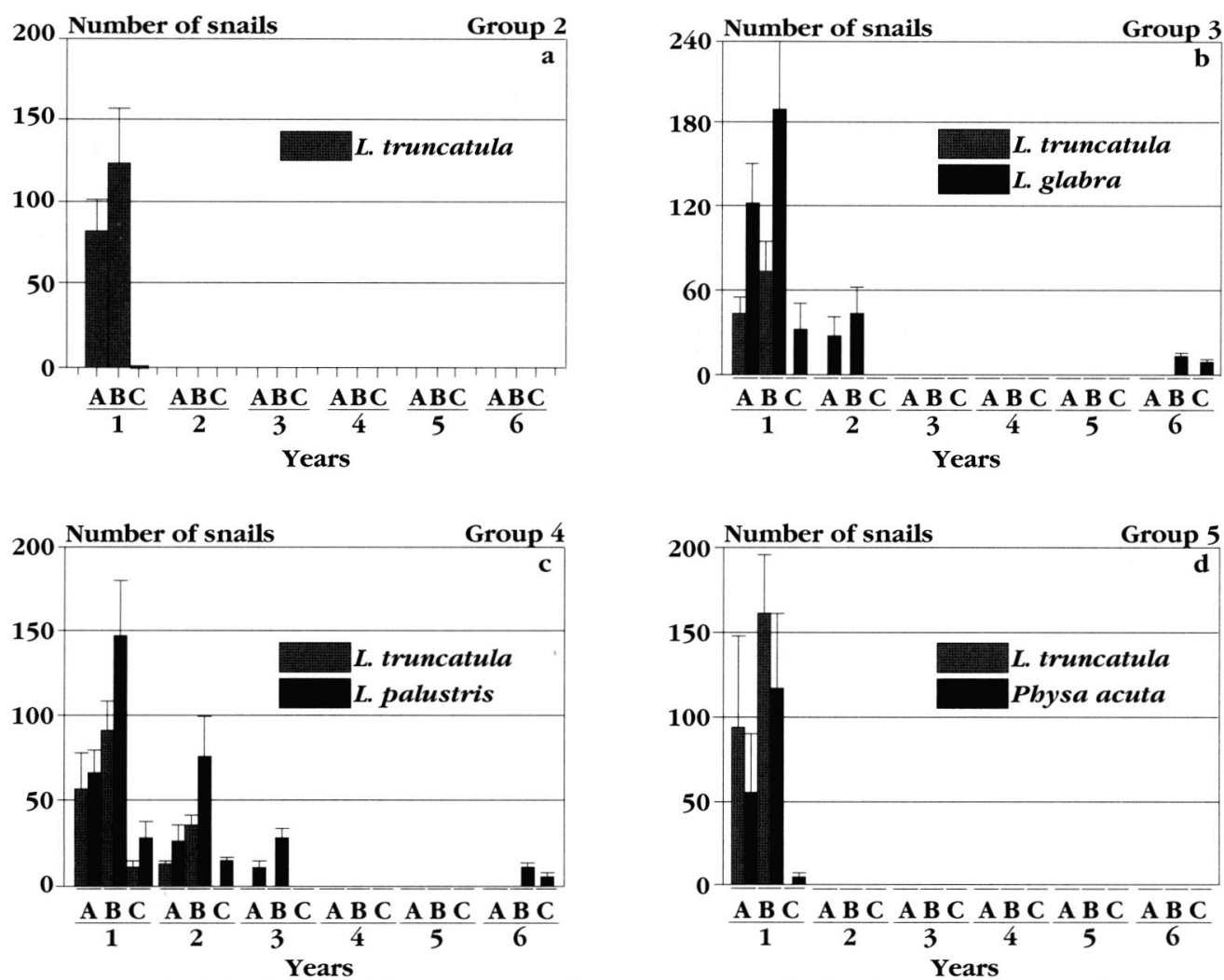

Fig. 2. - Numerical distribution of four aquatic snails in 17 watercress beds subjected to biological and chemical control measures. Mean values and standard deviations refer to sampling A, B and C made respectively in April, at the end of June, and in September.
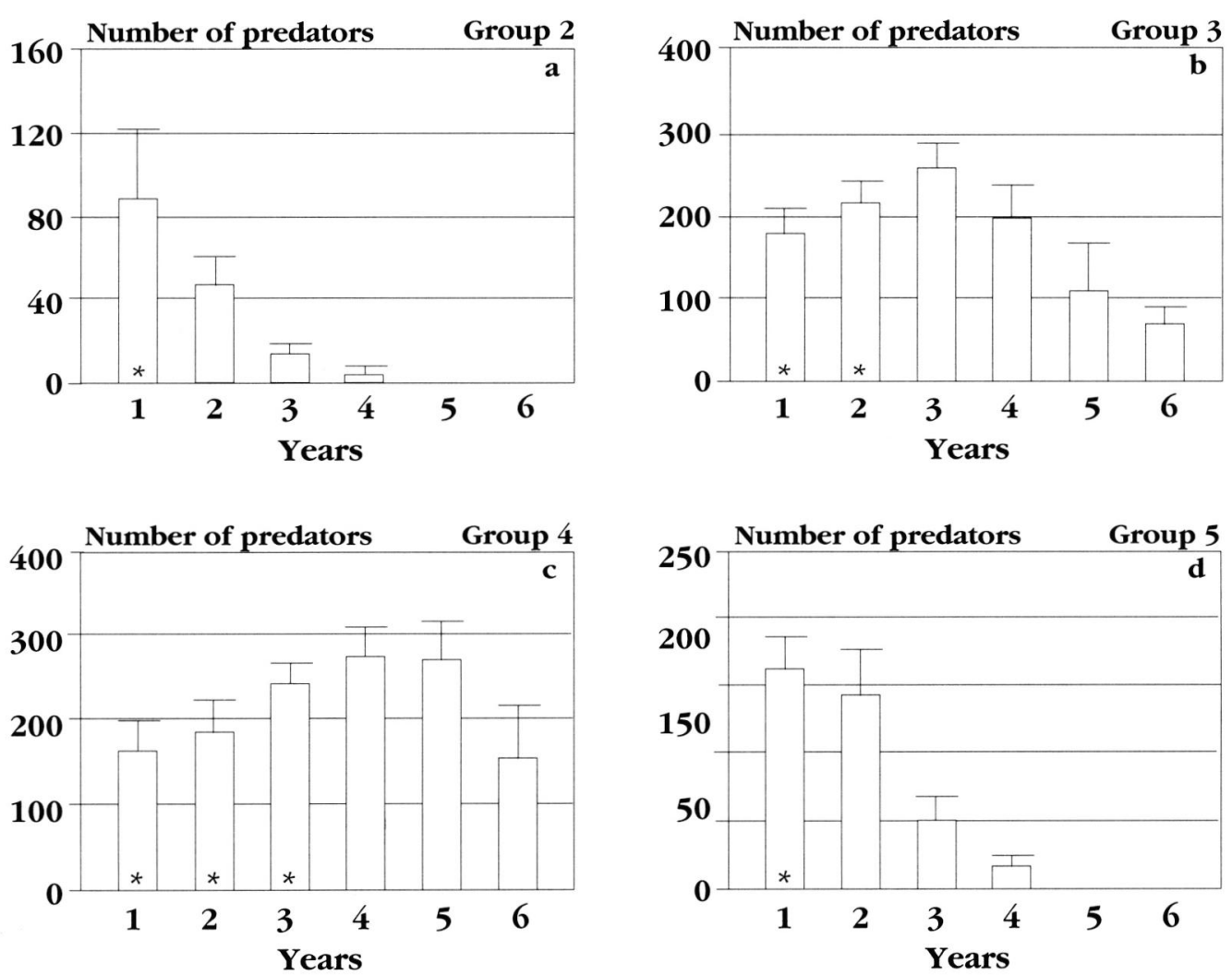

Fig. 3. - Numerical distribution of Z. nitidus in 17 watercress beds subjected to biological and chemical control measures (groups 2 to 5). Mean values and standard deviations refer to sampling B made just before the eventual introduction of other predators (with the exception of the first year). The asteriks indicate the years that the habitat control measures were applied. 
The numbers of $Z$. nitidus regularly decreased during the years following their introduction into group 2 sites. The mean value of 108 adult snails which were introduced in each station during the first year dropped to less than 3 snails per site during the 4th year at sampling B (Fig. 3a). The regular introduction of predators in the group 3 and 4 sites for two or three years resulted in increased numbers which persisted even one or two years after discontinuing treatment (Figs. 3b and c). A gradual decrease in numbers, however, was subsequently observed similar to that noted in the group 2 sites. The numerical outcome in the group 5 sites was identical to that noted in group 2 sites, with the disappearance of predators at the end of the 4th year of study (Fig. 3d).

The results obtained with mixed treatment of watercress beds were partially similar to those obtained by Rondelaud (1986, 1988) when this technique was used in swampy Limousin meadows. However, three points warrant special comment. First, it took a clearly greater length of time ( 2 or 3 years) to eradicate L. glabra or L. palustris from watercress beds than it did to eradicate L. truncatula. The time required for successful biological control of these two species was previously determined when Rondelaud (1978b) indicated that five successive years of treatment were required to eliminate $L$. glabra from its habitats using $Z$. nitidus. Although use of the toxic chemical certainly results in increased mortality of these snail species which go through the winter (Rondelaud, 1986), it is however clear that chemical treatment associated with predators is insufficient to eradicate these snails in only one year. This result may be explained by the watercress beds' greater depth and consequently by stream velocity, which is generally greater when L. glabra or L. palustris were present. One of the possible solutions to consider would be to increase the sublethal concentration of $\mathrm{CuCl}_{2}(0.5 \mathrm{mg} / \mathrm{l})$ and/or increase the volume of chemical which is poured into the treatment sites.

Secondly, recolonization of the treated habitats by $L$. glabra or L. palustris beginning from the 6th year of study can be explained by snail migration from areas downstream and from the same water drainage system. These two species would thus be capable, like $L$. truncatula (Moens, 1982), of migrating upstream against the water current, requiring a time period ( 2 to 3 years) that Rondelaud (1983) reported for L. truncatula during reinvasion of swampy meadows after the snail was eradicated using biological methods. The absence of habitat recolonization by L. truncatula can be explained by the time period ( 7 to 10 years) required by the snail to invade watercress beds previously treated by a biological method (Ximenes, 1991).

Thirdly, the gradual numerical decrease of $Z$. nitidus in watercress beds colonized by L. truncatula concords with what Rondelaud (1982) reported for beds of rushes on slopes and river banks treated by a biological method. On the other hand, the temporary spread of the predator in sites colonized by two snails is more difficult to interpret. The most plausible hypothesis is that living conditions in these last sites were most favourable for colony development and that the final numerical decrease was linked to the progressive disappearance of potential prey.

\section{REFERENCES}

Euzeby J. : Les maladies vermineuses des animaux domestiques et leurs incidences sur la pathologie humaine. Tome II. Fasc. 1. Livre 1. Vigot frères, Paris, 1971, 798 p.

MoEns R. : Mécanisme de réinfestation par Lymnaea truncatula des terrains propices à la fasciolose. Malacologia, 1982, 22, 29-34.

Rondelaud D.: Le comportement des Limnées tronquées (Lymnaea (Galba) truncatula Müller) saines ou infestées par Fasciola hepatica L. en présence de leurs prédateurs. Ann. Parasitol. Hum. Comp., 1978a, 53, 63-74.

Rondelaud D.: Les effets à long terme d'un contrôle biologique par prédation. Étude expérimentale de la dynamique de plusieurs espèces de Mollusques. Ann. Parasitol. Hum. Comp., 1978b, 53, 215-222.

Rondelaud D.: Données épidémiologiques sur la distomatose humaine à Fasciola bepatica L. dans la région du Limousin, France. Les plantes consommées et les limnées vectrices. Ann. Parasitol. Hum. Comp., 1980, 55, 393-405.

Rondelaud D.: Le contrôle biologique par prédation de Lymnaea truncatula Müller. Etude expérimentale de la dynamique de cinq espèces de Mollusques après arrêt du traitement. Malacologia, 1982, 22, 697-700.

Rondelaud D.: Les réseaux de drainage superficiel et leur colonisation par Lymnaea truncatula Müller. A propos de quatre années d'observations en Haute-Vienne. Ann. Rech. Vét., 1983, 14, 57-63.

Rondelaud D.: Le contrôle mixte et alterné de Lymnaea truncatula Müller par voie chimique et biologique. Premiers essais expérimentaux sur le terrain. Ann. Rech. Vet., 1986, 17, 15-20.

Rondelaud D.: Le contrôle mixte et alterné de Lymnaea truncatula Müller. A propos de trois techniques pour l'épandage du molluscicide. Ann. Rech. Vét., 1988, 19, 279-282.

Rondelaud D., Mage C.: The natural watercress ponds in Limousin (France) and their infection by Fasciola bepatica. Bull. Soc. Fr. Parasitol., 1990, 8, Suppl. 2, 692.

TAYlor E.L.: Fascioliasis and the liver fluke. F.A.O. Agricultural Studies, 1964, $n^{\circ}$ 64, $234 \mathrm{p}$.

Ximenes T.: Le contrôle biologique de Lymnaea truncatula Müller, hôte intermédiaire de Fasciola bepatica L. Possibilités et perspectives. Thèse Doct. Vét., Alfort, 1991, $n^{\circ} 122,103 \mathrm{p}$.

Accepté le 2 janvier 1994 